\title{
Lung Khe and the Cultural Relationship between Northern and Southern Vietnam
}

\author{
Lê Thi Liên \\ Vietnam Academy of Social Sciences \\ lelien_thi@hotmail.com
}

\begin{abstract}
This paper focuses on the area surrounding Lung Khe, which is the local name of an ancient citadel located in Thuan Thanh District, Bac Ninh Province, northern Vietnam. The nearby Nam Giao học tổ (南交學祖) Temple and the Tứ Pháp Buddhist temples, as well as records related to Shi Xie (士熟), the head of the Jiaozhi Commandery (交州太 守), indicate that interesting cultural exchanges occurred in this area. Examining archaeological evidence found by the late Dr. Nishimura Masanari and his colleagues, the paper discusses cultural relationships and contacts among ancient peoples in various areas, particularly in present-day northern and southern Vietnam.
\end{abstract}

\section{Keywords}

cultural contacts - Lung Khe Citadel - maritime network - Nishimura Masanari

\section{The Context of Cultural Exchange and Interaction in the Age of Shi Xie}

The latter half of the first millennium BCE and the first half of the first millennium CE witnessed the flourishing of a maritime trade network between the East and the West that was based on the demand for Chinese silks and luxury

* I would like to express my gratitude to Professor Aoyama Toru and Dr. John Guy for refining my English and editing the paper. I sincerely thank Mrs. Nishino Noriko for encouraging me and for organizing a series of wonderful papers to commemorate the late Dr. Nishimura Masanari. 
goods from the Mediterranean world. ${ }^{1}$ The rise of a mercantile community and the development of trade and craft guilds in India between 200 ВСE and 300 CE was another important factor. ${ }^{2}$ This situation created good opportunities for Southeast Asian people, including coastal groups in Vietnam, to adopt new knowledge and technologies for the development of local cultures and civilization. In central and southern Vietnam, strong cultural influences from India and the Mediterranean contributed greatly to the early states of Linyi (林邑) and Funan (扶南). At the same time, the successful Chinese conquest resulted in great changes in social organization in northern Vietnam, where elements of Han culture were forcefully imposed on local people. This is evidenced by the widespread presence of brick tombs containing Chinese-style artifacts and traces of Chinese-influenced burial ceremonies. ${ }^{3}$ The demand for goods, raw material, food, and other consumer products also resulted in a prosperous local economy. Population density rose during the last centuries BCE and early centuries $\mathrm{CE}$, as demonstrated by the increased number of settlements and burial sites discovered in the vicinity of the coastline and at the mouths of major rivers, including, for example, the Mạo Khê, Yên Hưng, and Bí Thượng sites (Quảng Ninh) as well as the Thủy Nguyen site (Hải Phòng) on the Hồng River and its branches; ${ }^{4}$ the Đông Sơn and Thiệu Duong sites in the Mã River valley; the Làng Vạc site on the Cả River; Lai Nghi and other sites on the Thu Bồn River; and the swampy sites at the mouth of the Đồng Nai River. The roles and status of lords or chieftains involved in commercial, political, and foreign affairs, or cultural exchange, are clearly identified by the variety and luxury of

1 Brigitte Borrel et al., "Contact between the Upper Thai-Malay," in Before Siam, ed. Nicolas Revire and Stephen A. Murphy (Bangkok: River Books and the Siam Society, 2014), 110-112.

2 Romila Thapar, A History of India, vol. 1 (New Delhi: Penguin Books, 1992), 109-115; Himanshu Prabha Ray, "Multi-Religious Linkages across the Bay of Bengal during the First Millennium CE," in Before Siam, 144.

3 References to types of vaulted brick graves and the use of grave goods can be found in Olov R. T. Jansé, Archaeological Research in Indo-China, vol. 1 (Cambridge, MA: Harvard University Press, 1947); Marilynn Larew, “Trở lại với Jansé: Đồ tùy táng ở Thanh Hóa” (Return to Janse: The Grave Goods in Thanh Hoa), in Một thế kỷ Khảo cổ học Việt Nam (One Century of Vietnamese Archaeology), vol. 2 (Hanoi: Social Sciences Publishing House, 2005), 23-46.

4 Brick tombs of Han types were discovered in various places and coastal areas, including those from Quảng Ninh Province, as reported in Đỗ Văn Ninh, "Báo cáo khai quật khu mộ Hán Mạo Khê, Quảng Ninh" (Report of the Excavation at Mao Khe Cemetery from the Han Dynasty, Quang Ninh) (unpublished report of the Institute of Archaeology, 1972), and in Lê Thị Liên, Bùi Thanh Hợi, and Kiều Đinh Sơn, "Báo cáo khai quật mộ cổ Bí Thượng, Uông Bí, Quảng Ninh" (Excavation Report on the Bi Thuong Ancient Tomb, Uong Bi Town, Quang Ninh) (unpublished report of the Institute of Archaeology, 2006). 
imported grave goods, such as those found at the sites of Việt Khê (Hải Phòng), Lai Nghi (Quảng Nam), and the Giồng Lớn (Bà Rịa-Vũng Tàu) sites (Figs. 1-2). ${ }^{5}$ Meanwhile, in India, the ideas of King Asoka encouraged "peaceful" cultural exchanges with other counterparts in various ways, including through religious practices, as suggested by Himanshu Prabha Ray. ${ }^{6}$ The strong impact of Indian religious practices in various areas, such as their role in the royal courts of rising powers in early Southeast Asia, is clear from both archaeological data and historical records.

In northern Vietnam, Indian ways of religious practice developed, at least during the second century CE. The Đại Việt sử ký toàn thu' (大越史記全書) records that whenever Shi Xie (士㶹, Vietnamese: Sĩ Nhiếp/Tiếp) went out, bells and gongs were rung and musical instruments were heard far and wide. The road was crowded with carriages, and the Hu people (probably Indians) went along burning incense. ${ }^{7}$ In the thirteenth-fourteenth century, Vietnamese Buddhist monks recorded the arrival of several monks in Vietnam, by both land and sea, during the Han period. Chinese texts such as Wuzhi (吳志), Tantian (谈天), Fawushilu (法務實錄), Gaozengzhuan (高僧傳), and Fozu Lidai Tongzai) (佛祖歷代通載) record the presence of Buddhism in Jiaozhou in the

5 A large number of graves of various types reflecting both the Đông Sơn and Han cultural characteristics of the owners have been found at the Đông Sơn and Thiệu Dương sites in Mã River Valley, and at the Làng Vạc site in Lam River Valley, as reported in Hà Văn Tấn, ed., Khảo cổ học Việt Nam (Vietnamese Archaeology), vol. 2 (Hanoi: Social Sciences Publishing House, 1999), 209-26o. In the Thu Bồn River Valley, the graves found at Lai Nghi and other sites contain luxury grave goods originating from India, as reported in Lam Thi My Dzung, "Sa Huynh Regional and Inter-regional Interactions," BIPPA 29 (2009): 68-75, figs. 1-2. Near the mouth of the Đồng Nai River, artifacts of both Indian and Han styles have been unearthed at several sites, as reported in Bùi Chí Hoàng, Phạm Chí Thân, and Nguyễn Khánh Trung Kiên, Khảo cổ học Bà Rịa Vũng Tàu (Archaeology in Bà Rịa Vũng Tàu) (Hanoi: Social Sciences Publishing House, 2012), 57-110; Vũ Quốc Hiền and Lê Văn Chiến, "Khai quật di tích Giồng Lớn 2003" (The Excavation at Giong Lon Site in 2003), in Thông báo khoa học 2006 (Scientific Information 2006) (Hanoi: Vietnam National Museum of History, 2006), 21-41; Vũ Quốc Hiền, Trương Đắc Chiến, and Lê Văn Chiến, "Khai quật di tích Giồng Lớn lần thứ hai" (The Second Excavation at Giong Lon Site), in Thông báo khoa học 2007 (Scientific Information 2007) (Hanoi: Vietnam National Museum of History, 2007), 19-43.

6 Ray believes that the diverse channels of communication, including oral transmission by priests and pilgrims, traders, wandering storytellers, and entertainers, brought about cultural exchanges across the Bay of Bengal. Ray, "Multi-Religious Linkages across the Bay of Bengal," 149 .

7 Đại Việt sử ký toàn thu' (Complete Annals of Đại Việt), trans. Viện Khoa học Xã hội Việt Nam (Hanoi: Social Sciences Publishing House, 1993), 25-27. Shi Xie headed the Jiaozhi Commandery from 187 to $226 \mathrm{CE}$. 


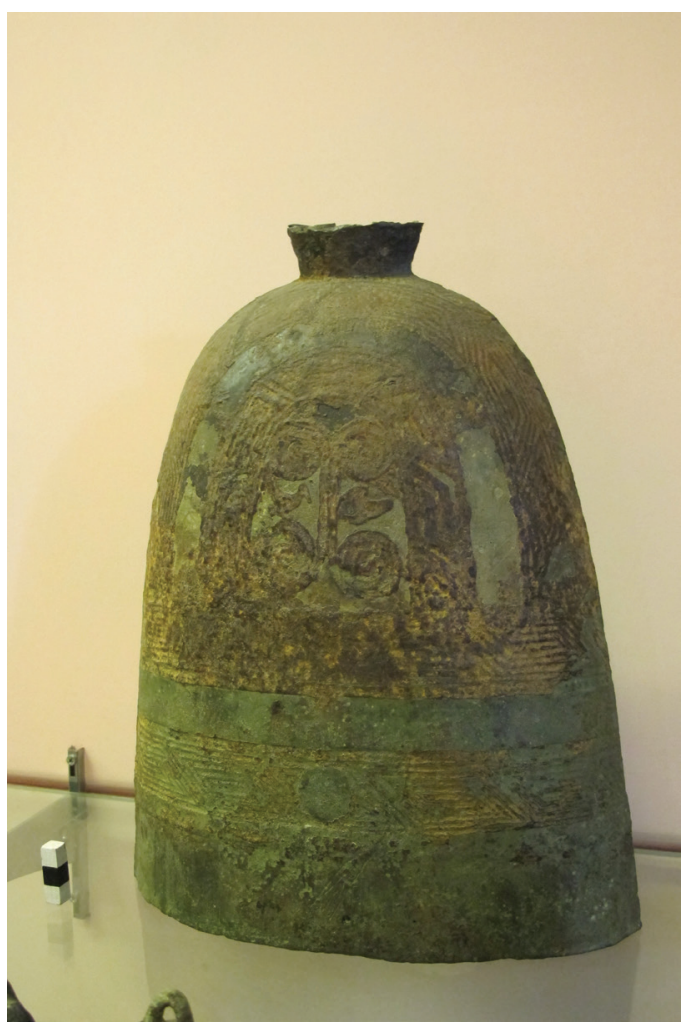

FIGURE 1

Chinese-style bronze bell from the Việt Khê tomb (Hải Phòng Province).

PHOTO: LÊ THİ LIÊN.

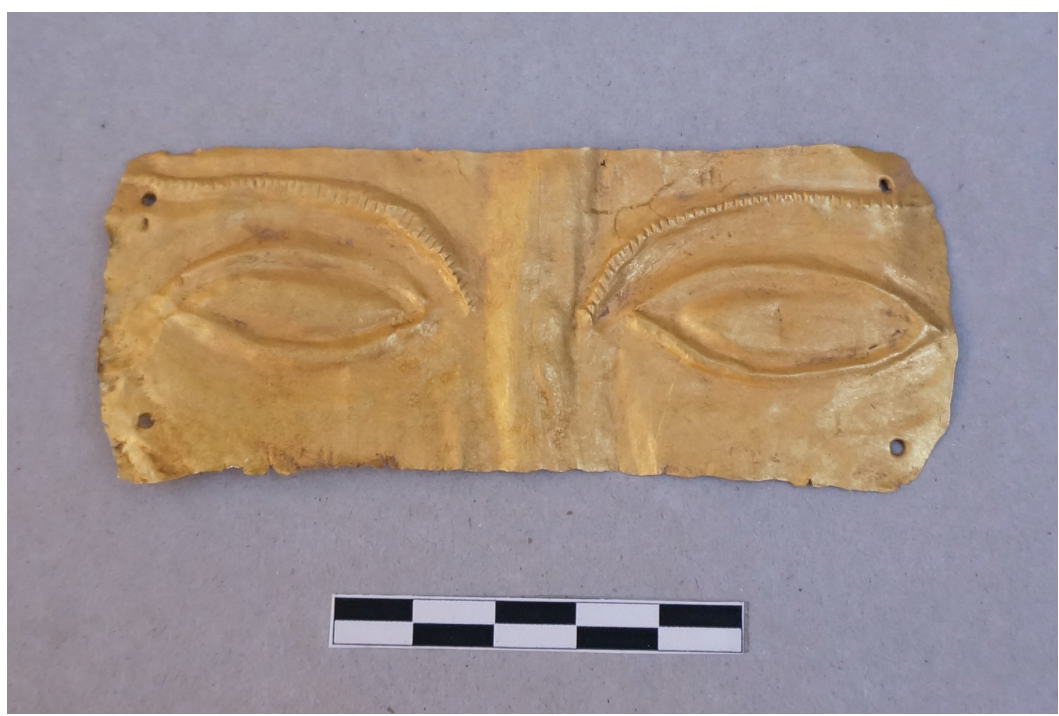

FIGURE 2 Gold mask from the Giồng Lớn site (Bà Rịa-Vũng Tàu Province). PHOTO: TRƯ'ƠNG ĐẮC CHIÊN. 


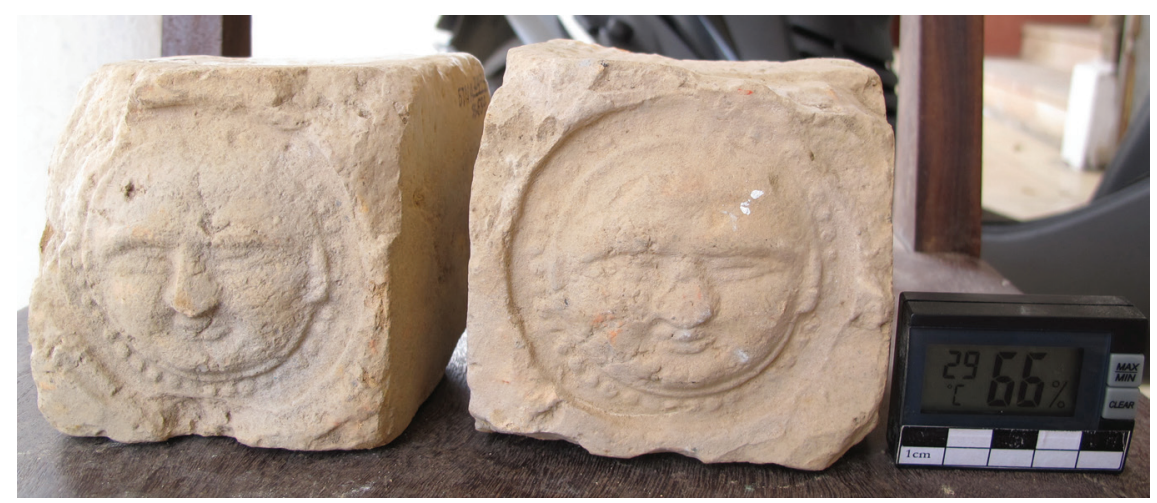

FIGURE 3 Human faces in the Chinese style on bricks found at the Nhạn Tháp stupa, NghệAn Province.

PHOTO: LÊ THỊ LIÊN.

early Christian era. ${ }^{8}$ During their domination, the Chinese tried to control and integrate local people under a central administration and a common culture, resulting in the so-called East Asian cultural sphere. This is reflected not only in administrative but also cultural policies, as indicated by the construction of a stupa by order of Yang Jian, Emperor Wen of the Sui (隋文帝), in 601 CE in the Bắc Ninh area, and the construction of the Nhạn Tháp stupa in Nghệ An during the Tang Dynasty. ${ }^{9}$ However, the real power of the so-called local autonomy in northern Vietnam and the expansion of the maritime network probably created good opportunities for contact and exchange with the so-called Indianized kingdoms, and for the absorption of cultural and religious ideas directly from India. Decorated bricks founded at the Nhạn Tháp stupa site contain artistic motifs of the Sui-Tang period, such as rounded faces on tile ends (Fig. 3) as well as the Trinity Buddha images with a roundish halo in the Gupta style.

In central Vietnam, the domination of the Han Dynasty ended after the rebellion of Khu Liên (區連) in Xiang Lin in 137 CE. Cultural and religious influences from India contributed greatly to the civilization of the Champa people. However, common cultural elements of Chinese origin are still seen in the

8 Mật Thể, Việt Nam Phật giáo sử lược (Brief History of Vietnamese Buddhism) (Hanoi: Minh Duc Publishing House, 1960), 63-74.

9 Phạm Lê Huy, "Nhân Thọ xá lợi tháp và văn bia tháp xá lợi mới phát hiện tại Bắc Ninh" (Nhân Thọ Śarīra Stupa and Śarīra Stupa Inscription Newly Found in Bac Ninh Province), Khảo cổ học (Archaeology) 181 (1-2013): 60-80; Trần Anh Dũng and Nguyễn Mạnh Cường, "Tháp Nhạn ở Nghệ Tĩnh qua hai lần khai quật" (Nhan Stupa in Nghe Tinh Province after Two Excavations), Khảo cổ học (Archaeology) 3 (1987): 69-83. 
archaeological record, particularly at the Hồ Citadel (Phú Yên Province) and the Trà Kiệu Citadel (Quảng Nam Province) during the first half of the first millennium. There are several types of artifacts showing affinities with those found in the Lung Khe Citadel, such as tile ends with a mask motif. ${ }^{10}$

In southern Vietnam, the first centuries CE witnessed the emergence of Funan, the first state in Southeast Asia, as attested by archaeological evidence unearthed from hundreds of sites of the Óc Eo Culture. ${ }^{11}$ The flourishing of maritime trade transformed Óc Eo, Nền Chùa, Cạnh Đền, and other locations into international meeting places for trade and cultural exchanges. The presence of foreign traders, pilgrims, politicians, craftsmen, and probably immigrants, including the Chinese, may be inferred in several places on the basis of various types of artifacts. Small terracotta figurines from the Gò Tháp site, small bronze bells, a mirror, and a Buddha image of the Northern Wei style from Óc Eo suggest contact between the Óc Eo people and China, most probably through the maritime network via northern Vietnam during the first half of the first millennium CE (Fig. 4). ${ }^{2}$

Religious sculptures made of stone and wood became important products and perhaps were presented as diplomatic gifts to northern Vietnam, as suggested by the presence of a stone Buddha image at Bến Củi, Nam Định city. The sculpture closely resembles several stone Buddha images found in southern Vietnam (Fig. 5$) \cdot{ }^{13}$

10 Trần Quốc Vượng and Hoàng Văn Khoán, "Đầu ngói ống Trà Kiệu" (Tile Ends from Tra Kieu), in Nhũ̃ng phát hiện mới Khảo cổ học 1985 (New Archaeological Discoveries in 1985) (Hanoi: Social Sciences Publishing House, 1986); Nishimura Masanari, Archaeology and Ancient History of Vietnam (Betonamu no Koko-Kodaigaku) (Tokyo: Doseisha, 2011), figs. 122, 123 .

11 Typical sites and artifacts of Oc Eo culture found after the excavations of L. Malleret in Oc Eo field are discussed in Lê Xuân Diệm, Đào Linh Côn, and Võ Sĩ Khải, Văn hóa Óc Eo-Nhũng khám phá mới (Óc Eo Culture—Recent Discoveries) (Hanoi: Social Sciences Publishing House, 1995); Bùi Phát Diệm, Đào Linh Côn, and Vương Thu Hồng, Khảo cổ học Long An—Nhũng thế kỷ đầu Công nguyên (Long An Archaeology—The Early Centuries CE) (Long An: Department of Culture and Information, 2001).

12 Louis Malleret, L'archéologie du Delta du Mekong, vol. 2 (Paris: EFEO, 1960), pls. XCI, XCII; Lê Thị Liên, "Excavations at Minh Su Mound, Go Thap site, Dong Thap Province, South Vietnam, 2000-2003," in Uncovering Southeast Asia's Past, ed. Ian Glover, Vincent C. Pigott, and Elisabeth A. Bacus (Singapore: NUS Press, 2006), 232-244, fig. 25.

13 Lê Thị Liên and Tống Trung Tín, "Về một pho tượng Phật đang được lưu trũ̃ trong Bảo tàng Nam Hà" (On a Buddha Statue Stored in Nam Ha Museum), in Những phát hiện mới khảo cổ học năm 1993 (New Archaeological Discoveries in 1993) (Hanoi: Social Sciences Publishing House, 1994), 193. 


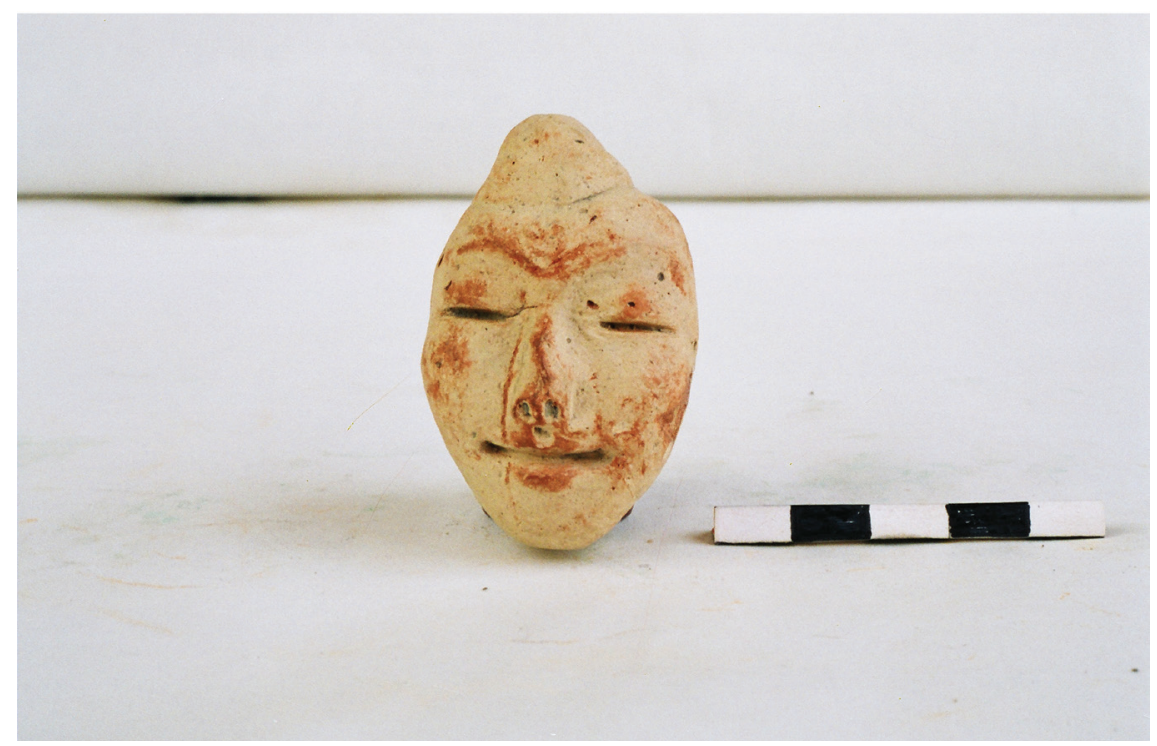

FIGURE 4 Chinese-style human head from the Gò Tháp site, Đồng Tháp Province. PHOTO: LÊ THİ LIÊN.

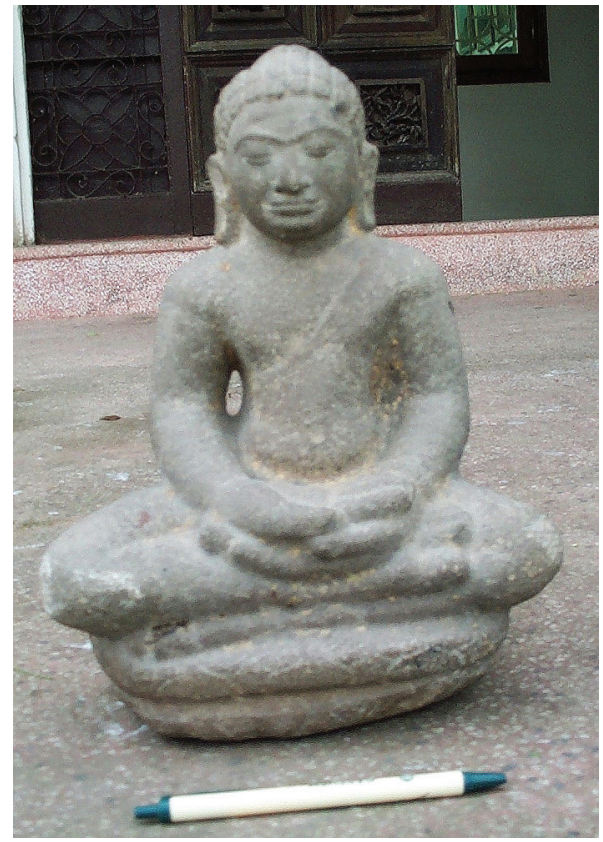

FIGURE 5

Stone Buddha image from Bến Củi, Nam

Định city.

PHOTO: LÊ THİ LIÊN. 


\section{Archaeological Discoveries at the Lung Khe Citadel}

Since the 1970s, the ancient citadel of Lung Khe has been surveyed and excavated several times by the Institute of Archaeology, the University of Social Sciences and Humanity (Hanoi), the Vietnam National Museum of History, and Bac Ninh Province, with the participation of Dr. Nishimura Masanari in 1998, 1999, and 2001. A five-year international co-operative project between the Vietnam National Museum of History, the Department of Culture, Sport, and Tourism of Bac Ninh Province, and the University of East Asia (Japan) is in progress, and excavations were conducted in 2014-2015 and 2016. Archaeological evidence indicates that the citadel was built in the second century $\mathrm{CE}$, continued in its original role until the late fifth-early sixth century, and was maintained until the tenth century. ${ }^{14}$ It was Dr. Nishimura who discovered a fragment of a Dong Son mold for casting a bronze drum in Lung Khe during a survey in 1998, and a second fragment in a stratigraphic layer dated to the second-third century CE. Vestiges of several bronze casting furnaces were also discovered during his excavation in 2001. This type of bronze drum has been classified by Imamura Keiji

14 Results of the excavations at Lung Khe (also called Luy Lâu in some reports) can be found in Tống Trung Tín and Lê Đình Phụng, "Báo cáo nghiên cứu khu di tích Luy Lâu, Thuận Thành, Hà Bắc năm 1986” (Research Report on Luy Lau Site, Thuan Thanh District, Ha Bac Province in 1986) (unpublished report by Institute of Archaeology, 1986); Trần Đình Luyện, "Một thế kỷ nghiên cứu Luy Lâu và những vấn đề đặt ra" (One Century of Research at Luy Lau and the Questions Asked), in Một thế kỷ khảo cổ học Việt Nam (One Century of Vietnamese Archaeology) (Hanoi: Social Sciences Publishing House, 2005), 2:47-52; Nishimura Masanari, "Thành Lũng Khê: Nhận xét mới từ những điều tra khảo cổ học" (Lung Khe Citadel: New Remarks from the Archaeological Investigations), in Một thế kỷ khảo cổ học Việt Nam (One Century of Vietnamese Archaeology) (Hanoi: Social Sciences Publishing House, 2005), 2:53-71; Nguyễn Xuân Mạnh, Đặng Hồng Sơn, Phạm Thị Len, and Nguyễn Thị Biên, "Khai quật thành Luy Lâu, tỉnh Bắc Ninh năm 2014" (The Excavation at Luy Lau Citadel, Bac Ninh Province, in 2014), in Nhũng phát hiện mới khảo cổ học năm 2015 (New Archaeological Discoveries in 2015) (Hanoi: Social Sciences Publishing House, 2016), 322-325; Đoàn khai quật Luy Lâu, "Những phát hiện qua cuộc khai quật thành cổ Luy Lâu, tỉnh Bắc Ninh năm 2014" (The Discoveries from the Excavation at the Ancient Citadel of Luy Lau, Bac Ninh Province, in 2014), in Nhũng phát hiện mới khảo cổ học năm 2015 (New Archaeological Discoveries in 2015) (Hanoi: Social Sciences Publishing House, 2016), 325-329; Huang Xiaofen, Lê Văn Chiến, et al., Báo cáo sơ bộ kết quả khai quật di tích thành cổ Luy Lâu lần thứ 3 năm 2016 (xã Thanh Khương, huyện Thuận Thành, tỉnh Bắc Ninh) (Brief Report on the Result of the Third Excavation at the Ancient Citadel of Luy Lau in 2016) (unpublished report of Vietnam National Museum of History, January 2017). 
as Type 3 a, produced in the cities and distributed to hilly regions. ${ }^{15}$ More than thirty-eight fragments of bronze drum molds discovered in the 2014 excavation pits, together with other types of casting tools, provide further evidence of a workshop manufacturing Dong Son bronze drums at Lung Khe. ${ }^{16}$ Several types of tile ends decorated with lotus, kala face, and mask motifs have been discovered. The kala face and mask designs may be associated with those found at Trà Kiệu (Quang Nam Province) and the Ho Citadel (Phu Yen Province), and may be related to Indian culture during the early centuries CE (Figs. 6-7) ${ }^{17}$ The Buddhist motifs of lotuses, lilies, and rhinoceroses on pipa leaves are similar to those found in Sui-Tang China, and even appear as late as the Lý Dynasty of Đại Việt (eleventh-twelfth century).18

Several artifacts signifying a cultural relationship between central and southern Vietnam were found at Lung Khe, among which a kendi of Malleret's Type 45, a fishing net, and a stone pesani are noteworthy. Several elements of local, Indian, and Chinese cultures are combined on a kendi found in the Nghi Ve brick tomb. ${ }^{19}$ In 2003, Nishimura Masanari joined the third excavation at the Minh Sư Mound (Gò Tháp, Đồng Tháp Province). He analyzed the pottery assemblage unearthed at the site and recognized a potsherd that was similar to those found at Lung Khe (Fig. 8). A small pot containing traces of lime was also noted.$^{20}$ Earlier in 2000, Nishimura joined the excavation at the Nhơn Thành site (Cần Thơ Province). Among the artifacts he analyzed was a small vase with two handles on the shoulder and peeled glaze, identified as an example of the

15 Imamura Keiji, "The Distribution of Bronze Drums of the Heger I and Pre-I Types: Temporal Changes and Historical Background," Bulletin of the Department of Archaeology, the University of Tokyo (東京大学考古学研究室研究紀要) 24 (2010): 3, 29-44.

16 Đoàn khai quật Luy Lâu, "Những phát hiện," 326-327.

17 Trần and Hoàng, "Đầu ngói ống Trà Kiệu," 235; Tống and Lê, "Báo cáo," 34, drawings 21, 24, 25; William A. Southworth, "Ngói mặt hề ở di chỉ Trà Kiệu" (Tile Decorated with Kala Face at Tra Kieu Site), in Nhũng phát hiện mới khảo cổ học năm 1994 (New Archaeological Discoveries in 1994) (Hanoi: Social Sciences Publishing House, 1995), 455-457; Trịnh Sinh and Nguyễn Kim Dung, "Vài suy nghĩ về niên đại sớm ở Trà Kiệu" (Some Thoughts on the Early Date at Tra Kieu), in Nhũng phát hiện mới khảo cổ học năm 1994 (New Archaeological Discoveries in 1994) (Hanoi: Social Sciences Publishing House, 1995), 457-458.

18 Tống and Lê, "Báo cáo," 29, figs. 14, 15, 20, 22, 23, 26, 27.

19 Nishimura, Archaeology and Ancient History of Vietnam, figs. 124, 125; Malleret, L'archéologie du Delta, pls. Xxxv, LI; Nishimura, "Thành Lũng Khê," fig. 7.4.

20 Nishimura Masanari, "Nhận thức bước đầu về đồ gốm địa điểm chân Gò Minh Sư" (Initial Awareness of the Pottery of the Site at the Foot of Minh Su Mound), in Nhũng phát hiện mới khảo cổ học năm 2003 (New Archaeological Discoveries in 2003) (Hanoi: Social Sciences Publishing House, 2004), figs. 21, 19. 


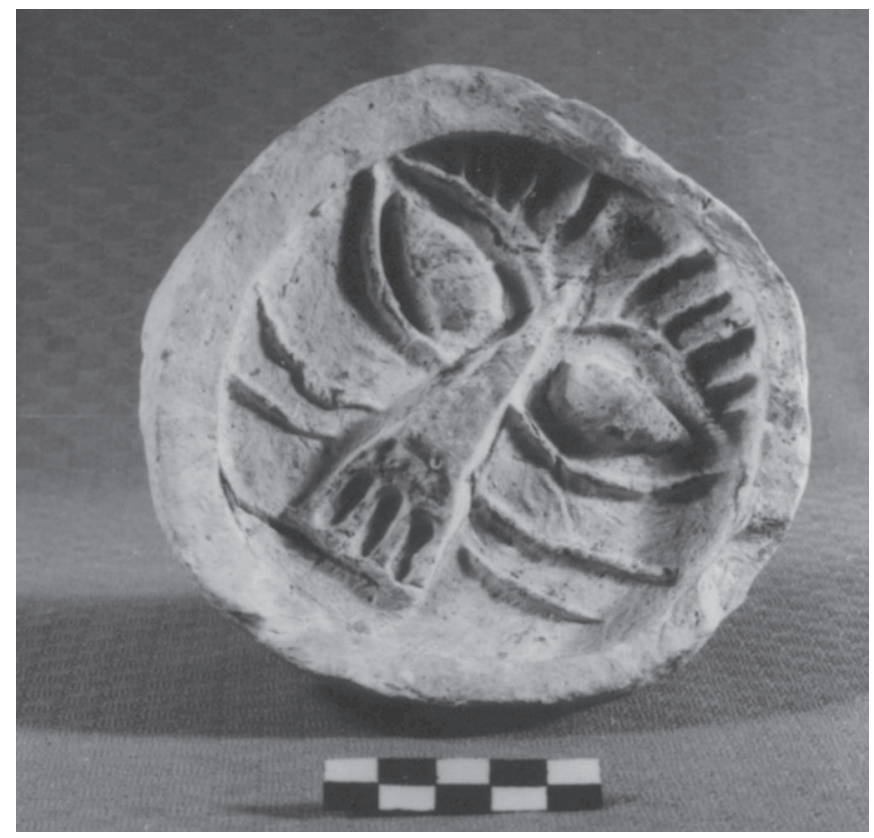

FIGURE 6 Tile end with mask design found at Luy Lâu. PHOTO: INSTITUTE OF ARCHAEOLOGY.

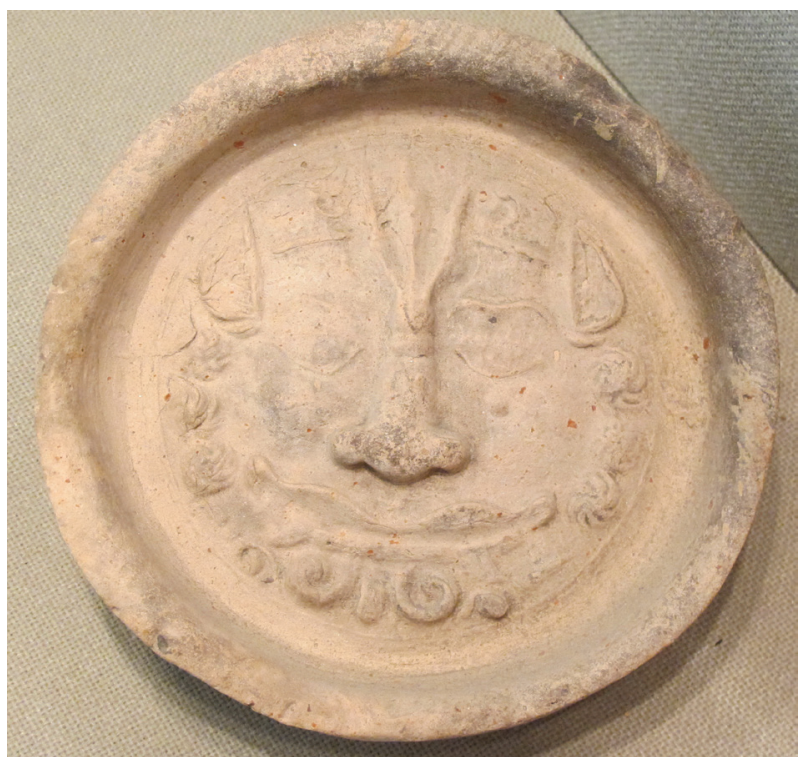

FIGURE 7 Tile end with mask motiffound at Trà Kiệu, Quảng Nam Province.

PHOTO: LÊ THİ LIÊN. 


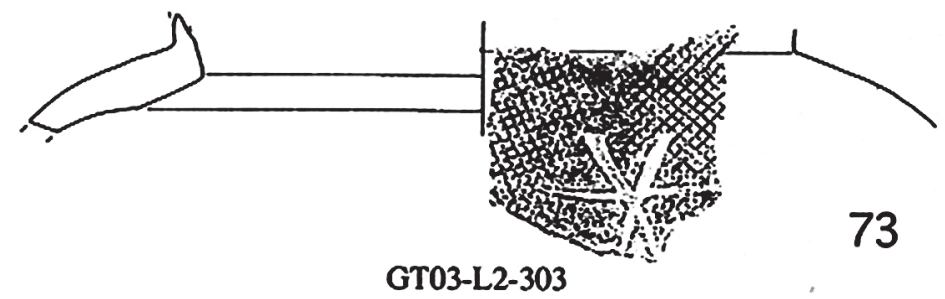

FIGURE 8 Potsherd from the Gò Tháp site, Đồng Tháp Province. DRAWING: NISHIMURA MASANARI.

Chinese Six-Dynasty style. Several pieces of stoneware with a brownish selfglaze were also found. These might have originated in northern Vietnam. ${ }^{21}$

\section{The Development of Buddhism in Vietnam: A Story from Lung Khe}

Closely related to the Lung Khe Citadel is a Buddhist center called Tư Pháp Buddhas (Four Dharma Buddhas). The 1986 investigation identified four Buddhist pagodas: Pháp Vân (Chùa Dâu), Pháp Vũ (Chùa Đậu), Pháp Lôi (Chùa Tướng), and Pháp Điện (Chùa Dàn). ${ }^{22}$ The Pháp Lôi Pagoda stood inside the southeastern corner of the citadel, and the others were located not far from the citadel. A legend related to these pagodas tells of a monk named Khâu Đà La and seems to agree with chronicle records that Indians were present during the time of Shi Xie. A handwritten text, which might be a copy of wooden boards dating back to the seventeenth or eighteenth century that were used in an offering ceremony in Dau pagoda, refers to this story. This text is noteworthy for the statement, "During the Later Han, (the Dau tree) being sanctification, Shi Wang (士王) made statutes that were held in reverence." 23 In the inscriptions and royal edicts of the Lê and Nguyễn dynasties (from the seventeenth to

21 Nishimura Masanari, Nguyễn Duy Tỷ, and Huỳnh Đình Chung, "Excavation of Nhơn Thành at the Hậu Giang River Reach, Southern Vietnam," Meishu Shi Yan Jiu Ji San (Journal of Fine Art History Research) 25 (2008): 1-71.

22 These are the Chinese literary epithets of the Buddhist temples that represent the natural elements of cloud, rain, thunder, and lighting. The temples also have local names, one of which (Chùa Dâu, "Mulberry Tree") reflects the legend that the statues were made from the mulberry tree.

23 Shi Wang refers to Shi Xie. I personally examined the manuscript kept by the abbot at the Dau Pagoda in 1986. 
the nineteenth century) housed in the Dâu Pagoda and the Tướng Pagoda, the Four Dharmas are referred to by several epithets: the Great God-Buddha, the Great God-Great Bodhisattva, and the Tutelary God (Fig. 9). ${ }^{24}$ Three wooden statues of this Buddhist group are now worshipped in Chùa Dâu and Chùa Dàn. Their artistic characteristics suggest a date in the seventeenth or eighteenth century. However, their iconographic features are unique. The wooden Dâu Lady Buddha has a feminine face that is beautiful but rather stiff, with a prominent urna on the forehead and snail-curled hair. The hands with large palms and the seated pose are typical of the Buddha in abhaya posture. The upper body is bare and the chest appears to be male (Fig. 10).

This type of Buddha cannot be found anywhere in the north and may reflect an older tradition that is now lost. Ruan Rongchun explained that the constituent features of the Jiaozhi Buddha statue are rather complicated, combining direct influences from Mathura and indirect influence from the Deccan by way of Funan. ${ }^{25}$ Along with these sculptures should be mentioned the wooden Buddha images of southern Vietnam. Buddha images made of wood constitute the most distinctive art style of southern Vietnam. Several Buddha images made of wood have been found at several sites, such as Giồng Xoài (Óc Eo), Nhơn Thành (Cần Thơ Province), and in the Đồng Tháp Mười area (belonging to Đồng Tháp and Long An provinces). About thirty images have been found at the Gò Tháp site (also known as the Plain of Reeds, Đồng Tháp Province). ${ }^{26}$

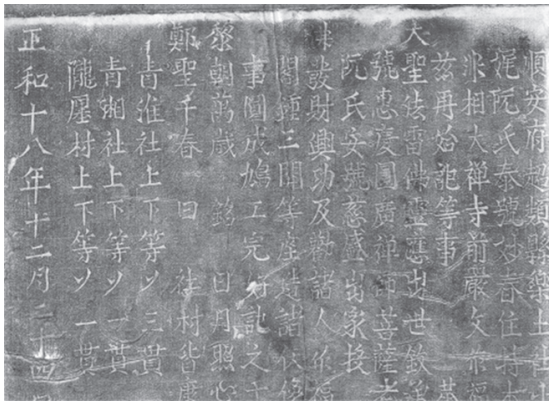

FIGURE 9

Stone inscription from Tướng (Pháp Lôi) Pagoda, Lung Khe Citadel. Rubbing: Lê Thi Liên.

24 Lê Thị Liên and Tống Trung Tín, "Tấm bia đá ở chùa Phi Tướng (Thuận Thành, Hà Bắc)" (The Stone Stele at Phi Tuong Pagoda, Thuan Thanh District, Ha Bac Province), Khảo cổ họ (Archaeology) 3 (1987): 84-89.

25 Ruan Rongchun, Fujiao Nanchuan Zhilu (The Southern-Spreading Route of Buddhism) (Henan: Meishu Chubanshe, 2000), 61-62.

26 Lê Thị Liên, Nghệ thuật Phật giáo và Hindu giáo ở đồng bằng sông Củ̉u Long trước thế kỷ X (Buddhist and Hindu Art in the Cuu Long River Delta prior to the Tenth Century) (Hanoi: Thế Giới Publishing House, 2006), 42-48. 


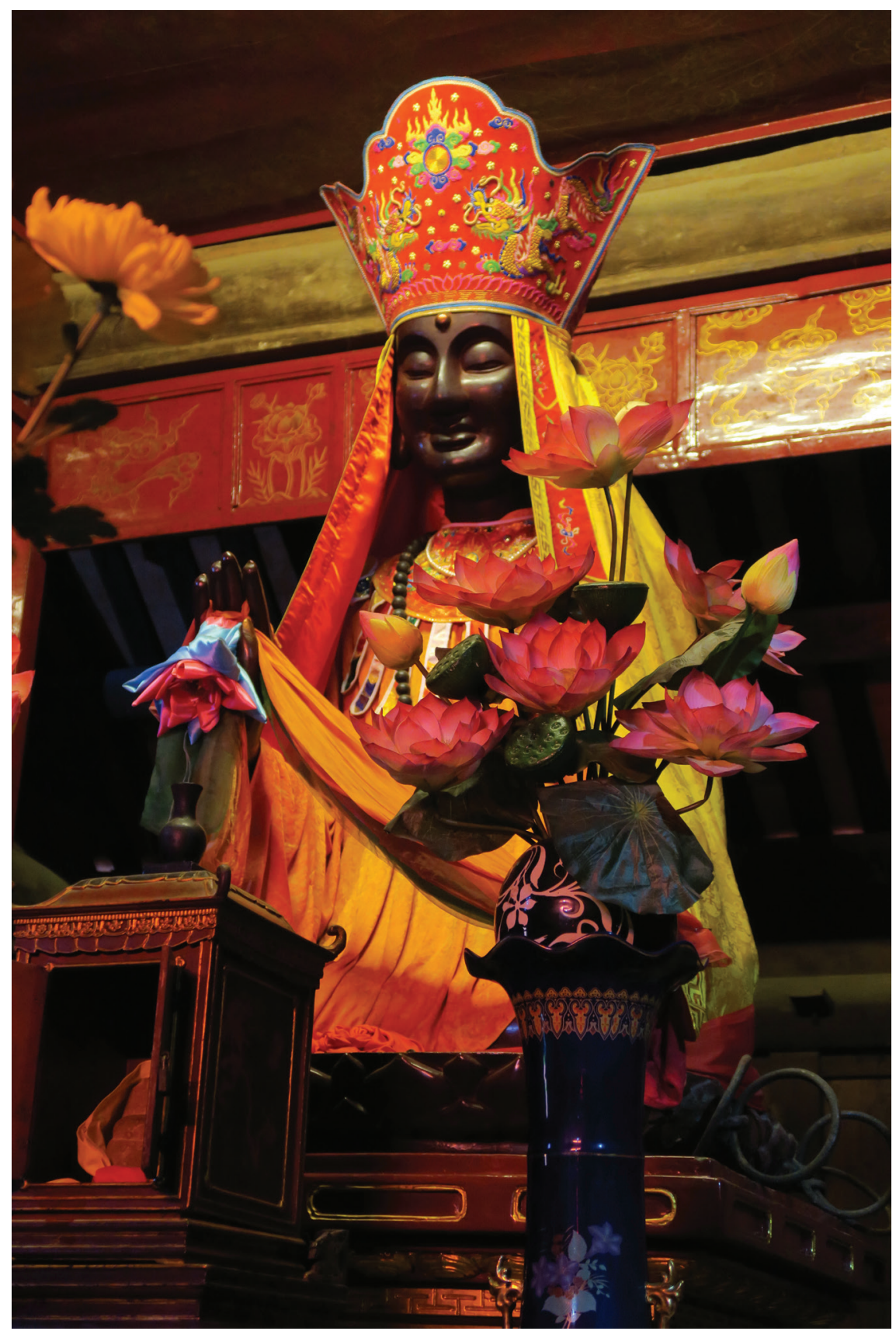

FIgURE 10 Wooden image of the Dâu Lady Buddha, Dâu pagoda, Thanh Khương village, Bắc Ninh Province.

PHOTO: LÊ THI LIÊN. 
Well-executed wooden Buddha images in various sizes represent a long tradition and show the influence of several schools of Indian art. The standing images can be classified into three groups. The first group includes those standing in the delicate tribhanga posture. Both the tallest and smallest examples belong to this group and were found in the Đồng Tháp Mười area. Their elongated bodies and legs represent the influence of the Amaravati style. Other features typical of this group include an elongated neck, a small face with a roundish chin, and a flat chest. This group can be dated to the earliest phase of the manufacture of wooden Buddha images in southern Vietnam, most probably from the second to the fourth century $\mathrm{CE}$.

The second group displays more elements that have been drawn from Gupta art at Sarnath, including the abhanga standing posture. Some images, mainly life size, represent the Great Man (mahapurusa). Chronologically, they date to the fifth-sixth century. These well-preserved images provide good examples for the study of Buddhist iconography and artistic features (Fig. 11). ${ }^{27}$

The third group contains features that are frequently seen in Dvaravati art, especially the stiff samabhanga posture. The best-preserved example was found in Phong Mỹ village at the southern end of the Đồng Tháp Mười area. There is no line on his strong neck. The broad shoulders and stiff body, as well as the two legs firmly planted on the lotus base and marked by prominent knees, are typical features of the Dvaravati style. ${ }^{28}$

It is interesting that evidence of workshops for manufacturing wooden Buddha images has been found at several sites, such as Gò Tháp, Nhơn Thành, and Giồng Xoài. Among these, the workshop at Gò Tháp may have been the largest. Regarding the woodwork, the mortise and tenon joinery used in the Động Xá boat burial (second century BCE) was also used to attach the arm to the body of wooden sculptures at the Gò Tháp manufacturing site. Therefore, the technique of manufacturing wooden Buddha images may have been shared among people in northern and southern Vietnam, including those from the Lung Khe area, during the first half of the first millennium.

A study of the pantheon of the present Dâu Pagoda indicates that it was probably modeled on the earlier Tứ Pháp system. ${ }^{29}$ The worship of the holy stone, Thach Cuong ("light-radiating stone"), may also be the product of a tradition other than Buddhism (Fig. 12). Similar phenomena are the worship of

27 Ibid., 46-47.

28 Ibid., fig. 19.

29 Tống Trung Tín, "Nhận xét về sơ đồ thượng điện các chùa Tứ Pháp" (Remarks on the Plan of the Main Shrine in the System of Four Dharma Pagodas), Khảo cổ học (Archaeology) 3 (1993): 46-53. 


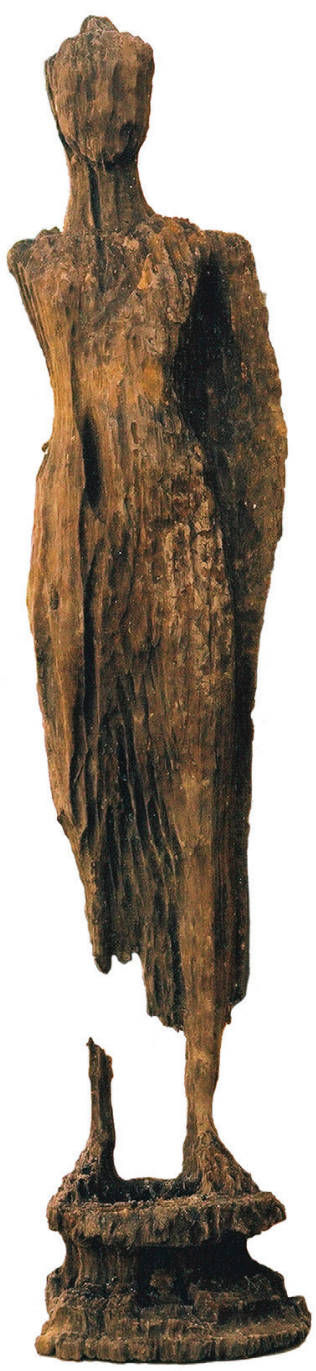

FIGURE 11

Buddha image in wood, Gò Tháp site, Đồng Tháp Province. PHOTO: LÊ THỊ LIÊN.

monoliths at the Nhất Trụ Pagoda (Hoa Lư, Ninh Bình), and of the "holy foot" in about twenty-two places in Vietnam. ${ }^{30}$ This cultural tradition provides more evidence for the early existence of Buddhism in Jiaozhou, as Tantian (Đàm Thiên) (542-607) reported to Emperor Wen of the Sui that the area of Jiaozhou had long been in communication with Tianzhu (天竺, referring to India): "Early

30 Nguyễn Duy Hinh, "Đền Độc Cước: Dấu chân thần—Biểu tượng Phật” (Mono-foot Temple: God's Footprint—Buddha's Symbol), Khảo cổ học (Archaeology) 1-2 (1988): 72-83. 


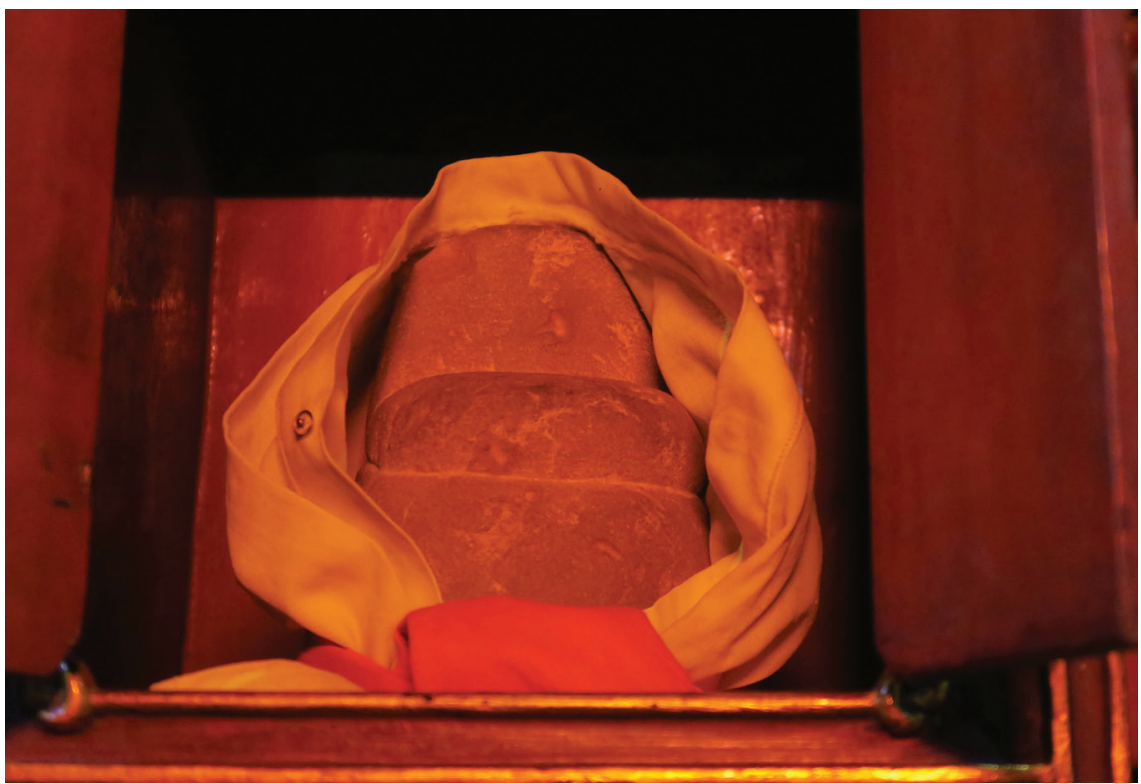

FIgure 12 Holy stone, Dâu pagoda, Thanh Khương village, Bắc Ninh Province. PHOTO: LÊ THİ LIÊN.

on, when the Buddha-Dharma reached Jiangdong (江东) and still had not been established (there), in Luy Lau (贏㜢) more than twenty temples had (already) been built, more than five hundred monks had (already) been ordained, and fifteen volumes of scriptures had (already) been translated."31

To sum up, data from archaeology, historical records, and traditional and existing culture and religion in the Lung Khe-Dâu area reflect the existence of an important political, cultural, and religious center in Jiaozhou during the first half of the first millennium CE. As Nishimura suggested, the data indicates that people from various backgrounds may have been involved in the Lung Khe government. They kept close contact with central and southern Vietnam and other cultures via the river system leading to the coast, which is now changed and some parts of which have been lost. Archaeological studies in recent years have unearthed more complex cultural layers and artifacts inside the citadel and in its periphery. However, as a political and Buddhist center of Jiaozhou

31 Kim Son, Thien uyen tap anh (Collection of Outstanding Figures of the Zen Garden 禪苑 集英), trans. Lê Mạnh Thát (Saigon: Vạn Hạnh University Press, 1999), 50. This event has been cited in Jayne Werner, John K. Whitmore, and George Dutton, Sources of Vietnamese Tradition (New York: Columbia University Press, 2012), 18. 
for several centuries, during a period that saw the emergence of several early states in Southeast Asia, the Lung Khe-Dâu area should be studied more systematically in its broader cultural context. The comparative study of historical documents, including the inscriptions and archaeology of Óc Eo, Champa, and other parts of northern Vietnam, will be helpful for understanding the relationships and cultural interactions in this region. 